\title{
New Approach for Using Different Forms of Sweet Sorghum Syrup in Cake Making
}

\author{
Soha R. Khalil ${ }^{1}$, Hanan A. Hussien ${ }^{2}$, Sakina R. Abazied ${ }^{1}$ \\ ${ }^{1}$ Sugar Crops Research Institute, Agriculture Research Center, Giza, Egypt \\ ${ }^{2}$ Food Technology Research Institute, Agriculture Research Center, Giza, Egypt \\ Email address: \\ Soharoot77@yahoo.com (S. R. Khalil)
}

\section{To cite this article:}

Soha R. Khalil, Hanan A. Hussien, Sakina R. Abazied. New Approach for Using Different Forms of Sweet Sorghum Syrup in Cake Making. World Journal of Food Science and Technology. Vol. 2, No. 2, 2018, pp. 25-32. doi: 10.11648/j.wjfst.20180202.11

Received: March 19, 2018; Accepted: April 23, 2018; Published: June 12, 2018

\begin{abstract}
The present work was carried out at Giza Agricultural Research Station, Giza Governorate, Egypt, to evaluate using different forms of sweet sorghum syrup for making cake. Two forms of sweet sorghum (Roma variety) juice were used as a sugar replacement with ratio $(10,20,30$ and $40 \%)$ for syrup and $(25,50,75$ and 100\%) for freeze-dried juice. Results showed that the syrup and freeze-dried juice were rich sources of both sugars and minerals which give its physico-chemical characteristics a wide spectrum of utilization in foods. The chemical properties indicated that the freeze- dried juice contained the highest value of sucrose, glucose, fructose, crude protein, phenols and minerals ( $\mathrm{K}, \mathrm{Ca}$ and $\mathrm{Fe}$ ) followed by syrup, respectively. Meanwhile freezedried juice product gave the highest value for HMF. The physical properties indicated that the sweetness acceptability and power sweetener-were higher in freeze-dried juice than syrup. The colour evaluation indicated that, the degree of browning and darkening is higher increased with syrup followed by freeze-dried juice. In regard to physical properties of cakes prepared with forms of sweet sorghum, the height, volume and specific volume of cake slightly decreased by sugar replacement up to $20 \%$ for syrup and $50 \%$ for freeze-dried, while the weight had significantly increased. Concerning crust and crumb color, the results indicated that a darker crust and crumb were increased with the increase of substitution levels. So, the cake applications with sweet sorghum forms of syrup are a suitable source for adding color to the cake by previous substitution levels that do not affect the quality. Organoleptically, cake showed insignificant difference between control (sucrose) cake and replacement with syrup (up to $20 \%$ ) or freeze-dried juices (up to $50 \%$ ), where it had high scores for crust and crumb color, texture, taste and flavor of cake.
\end{abstract}

Keywords: SWEET Sorghum Syrup, Freeze Dried Juice, Sugar Replacement and Cake Quality

\section{Introduction}

Sweet sorghum \{Sorghum bicolor L. Moench\} is a good multipurpose crop for production of grains, bagasse, syrup, and ethanol [3]. Almodares and Hadi [8] stated that, sweet sorghum has many criteria, it is easy cultivation by seeds, low fertilizer and water requirements, growth on marginal lands under various environmental stresses, short growth cycle (90 to 150 days) after planting (depending on variety and environment) that allows the possibility of multiple crops per season or rotation with other food or non-food crops, efficient C4 photosynthetic pathway and has wide geographical suitability. Sweet sorghum juice, was explored as a source of sugar alternative for food and beverage industry [14], the juice yields of sweet sorghum harvested at soft dough stage ranged from 7481 to 12626 liters/ha and 8587 to 13368 liters/ha in M81E and Topper varieties, respectively [9].
Abazied [3] found that, sorghum syrup prepared from dough ripening stage had reasonable quantity of simple sugars and it had acceptable quality resembling to cane syrup (treacle) that is found in the local market in Egypt and more economical to grow than sugar cane. Helmy [20] found that sucrose content in syrup of studied sweet sorghum varieties ranged from 27.03 to $30.63 \%$, purity of syrup ranged from 36.03 to $40.83 \%$ and reducing sugars was between 31.60 and $35.54 \%$. Al-Askalani and Khalil [7] evaluated the juice quality of fifteen sweet sorghum varieties and found that, TSS was (19.43 - 12.37\%), sucrose $(8.4-17.3 \%)$, reducing sugar $(1.01-3.20 \%)$, and nonsugar substances $(5.30-6.06 \%)$. Makori [26] showed that higher glucose and fructose of sweet sorghum juice is better to produce good quality of syrup, where Elena [15] found it can use partially substitute the sugar by syrup in food industry. Hatamipour et al. [19] found that the concentration of sweet 
sorghum juice decreased water activity and as a result microbial spoilage therefore; increasing the shelf life of the products.

Wilhelm et al. [37] reported that freeze drying method can produce high quality dried products. Thus, it is the preferred drying method for some high value materials. Khuenpet et al. [22] illustrated that sugarcane juice powder can be manufactured using the spray drying technique. In addition, the specific energy cost will be reduced if the sugarcane juice is concentrated by the evaporator before the spray drying process and also if the powder recovery percentage increases.

Sucrose plays a key role in cakes; it helps good incorporation of the air, so creating a more viscous and stable sponge [31]. In addition,-sucrose can retard gelatinization of the starch during baking, allowing better expansion of the bubbles due to the pressure generated by carbon dioxide and water vapour before the cake sets as Kim and Walker [23] explained. The stalk juice of sweet sorghum is rich in sugar, phenolic compounds with antioxidant and antiradical activities and also some minerals, which is considered an encouraging factor for uses in bakery industry [9]. In fact, it is suitable to utilize the sweet sorghum juice and its products as natural sweeteners in food industry, especially in high sugar bakery products as cakes in order to meet the sugar demands and close the vast gap between the production and consumption. Sweet sorghum syrup has physico-chemical characteristics that allow for wide exploitation in dessert and bakery industry [6]. ElGeddawy [16] found that sorghum syrup is easily substituted in recipes for cookies, biscuits, sweet bread, and candies as sugar substitute in other food products acceptable physiochemical and organoleptic properties.

The present investigation was carried out to evaluate different forms of sweet sorghum syrup i.e. (syrup and freeze-dried juice) which can be used as a sugar substitutes in cakes as well as to study their effects on cake quality.

\section{Materials and Methods}

The current study was carried out at Agricultural Research
Station, Giza governorate, Egypt, to evaluate different forms of sweet sorghum juice i.e. syrup and freeze-dried juice as a sugar substituted for making cake with a good quality. Roma sweet sorghum cultivar (Sorghum bicolor L. Moench) was used for this study. It was sown at the $1^{\text {st }}$ week of June, 2016 and harvested at dough stage (after 120 days of planting). Cake ingredients were purchased from local market.

Sweet sorghum products prepared as follows.

\subsection{Extraction, Filtration and Clarification of Juice}

The millable stalks were stripped and squeezed by electric three- roller horizontal mill, the extracted juice was drained through fine meshed screens or layers of cheesecloth into a large holding stainless steel tank then, the juice was clarified by treating extracted juice with calcium hydroxide solution $0.1 \mathrm{~N}$ according to Helmy [20].

\subsection{Syrup Processing}

The clarified juice was evaporated to obtain syrup with $73 \%$ brix according to method described by Abazied [3].

\subsection{Preparation of Freeze-dried Juice}

Clarified sweet sorghum juice was evaporated by rotary to $\left(73^{\circ}\right.$ Brix) then dried firstly by freezing and water portion separation, and then the concentrated portion was dried by oven under vacuum at $40^{\circ} \mathrm{C}$ to reach a complete dryness.

Amounts of sweet sorghum products: were determined by weighing the syrup or freeze-dried product which gave 0.452 $\mathrm{kg} / \mathrm{m}^{2}$ for syrup and $0.360 \mathrm{~kg} / \mathrm{m}^{2}$ for freeze-dried juice.

\subsection{Cake Preparation}

Cakes were prepared according to the AACC [2]. The sugar replacement was calculated according to the relativesweetness values of syrup and freeze-dried sorghum juice. The amounts are shown in (Table 1).

Table 1. The Ingredients of Cake ( $g$ ).

\begin{tabular}{|c|c|c|c|c|c|c|c|c|c|}
\hline \multirow{2}{*}{$\begin{array}{l}\text { Replacement } \\
\text { Ratio (\%) }\end{array}$} & \multicolumn{9}{|c|}{ Cake Components } \\
\hline & Wheat Flour & Butter & Dry Milk & Egg & Salt & $\begin{array}{l}\text { Baking } \\
\text { Powder }\end{array}$ & Sugar & $\begin{array}{l}\text { Sweet Sorghum } \\
\text { Syrup }\end{array}$ & $\begin{array}{l}\text { Freeze-dried } \\
\text { Sweet Sorghum Juice }\end{array}$ \\
\hline Control & 200 & 100 & 24 & 180 & 6 & 10 & 280 & - & - \\
\hline \multicolumn{10}{|c|}{ Cake with Sweet Sorghum Syrup } \\
\hline 10 & 200 & 100 & 24 & 180 & 6 & 10 & 252 & 21.28 & - \\
\hline 20 & 200 & 100 & 24 & 180 & 6 & 10 & 224 & 85.12 & - \\
\hline 30 & 200 & 100 & 24 & 180 & 6 & 10 & 196 & 127.68 & - \\
\hline \multicolumn{10}{|c|}{ Cake with Freeze-Dried Sweet Sorghum Juice } \\
\hline 25 & 200 & 100 & 24 & 180 & 6 & 10 & 210 & - & 87.5 \\
\hline 50 & 200 & 100 & 24 & 180 & 6 & 10 & 140 & - & 175 \\
\hline 75 & 200 & 100 & 24 & 180 & 6 & 10 & 70 & - & 262.5 \\
\hline 100 & 200 & 100 & 24 & 180 & 6 & 10 & - & - & 350 \\
\hline
\end{tabular}

The sugar replacement was calculated according to the relative-sweetness.

\subsection{Chemical Analyses of Syrup, Freeze-Dried Juice and Cakes}

The following parameters of chemical analysis were measured:

a) Moisture, total soluble solids\% (TSS), total sugar $\%$, reducing sugars $\%$, glucose ratio, starch $\%$, protein and 
ash were determined according to A.O.A.C. [1].

b) Non-sugar substances $\%$ was calculated by the following formula NSS $\%=$ TSS - (sucrose + reducing sugars) according to Fort and Mckaig [18].

c) Sugar fractions\% (sucrose, glucose and fructose) of syrup and freeze-dried powder were determined by using HPLC according to Long et. al. [30].

d) Phenolic compounds, quantified according to Folin and Ciocalteau [17].

e) 5-hydroxymethylfurfura (HMF) content (PPM) in syrup and freeze-dried juice were determined by using HPLC according to Jafarnia et al. [21].

f) Mineral Content (iron, calcium and potassium) in syrup and freeze-dried juice were measured by Atomic Absorption (Variam AA20) according to A.O.A.C. [1].

\subsection{Physical Properties of Syrup and Freeze-dried Juice}

The following parameters of physical properties were measured:

a) $\mathrm{PH}$ value was determined by $\mathrm{PH}$ meter according to A.O.A.C. [1].

b) Total acidity $\%$ was determined as $\mathrm{ml} \mathrm{Na} \mathrm{OH} 0.1 \mathrm{~N} / 100$ $\mathrm{g}$ sample and calculated $(\mathrm{mg} / \mathrm{m} \mathrm{Eq}$ as a predominant acid (citric acid) according to Chen and Picou [12]. Sweetness acceptability of syrup and freeze-dried juice samples were perceived by the sensory panel according to the method of Collins et al [13].

c) Collect power sweetener of sugars content in syrup and freeze-dried juice samples were determined according to ratio of fractionation of sugar as relative sweetness of sugars as follows sucrose $=1$, glucose $=0.69$ and fructose $=1.5$ times as much as sucrose according to Nan et al. [35]

d) The total colour value of syrup samples were measured by using Minolta colorimeter (model CM-3500d, Japan) according to method described by Ranganna [33] while the colour of freeze-dried juice as well as crust and crumb of cake were measured with a Hunter Lab Colorimeter (MiniScan XE Plus, Reston, VA) according to the method described by Abd El-Hady et al. [4] and recorded in the $L^{*} a^{*} b^{*} c^{*}$ colour system. Numerical total colour difference $(\Delta \mathrm{E})$ was calculated as follows: $\Delta \mathrm{E}=\left[\left(\mathrm{L}-\mathrm{L}_{0}\right)^{2}+\left(\mathrm{a}-\mathrm{a}_{0}\right)^{2}+\left(\mathrm{b}-\mathrm{b}_{0}\right)^{2}\right]^{1 / 2}$. Where $\mathrm{L}_{\mathrm{o}}, \mathrm{a}_{\mathrm{o}}$ and $\mathrm{b}_{\mathrm{o}}$ were the $L, a$, and $b$ values of the reference sample which herein is the control sample.

Hue $=\tan -1[\mathrm{~b} / \mathrm{a}] ;$ chroma $=\mathrm{a}^{2}+\mathrm{b}^{2} ; \mathrm{X}=(\mathrm{a}+1.75 \mathrm{~L}) /$

$(5.645 \mathrm{~L}+\mathrm{a}-3.012 \mathrm{~b})$

browning index $=[100(X-0.31)] / 0.172$.

\subsection{Physical Properties of Cakes}

Cake height was measured to the nearest millimeter with a micrometer. Volume (ml) was measured by seed displacement and weight $(\mathrm{g})$ was determined according to AACC, 2010 [2]. The measurements were performed in triplicate.

\subsection{Sensory Evaluation of Cakes}

Cake samples were left to $\operatorname{cool}\left(25^{\circ} \mathrm{C} \pm 2\right)$ for $4 \mathrm{~h}$ after baking then subjected to organoleptic characteristics. Cakes were judged for crust and crumb color, texture, taste, flavor, and overall score, by 10 well trained panelists from the staff of Food Technology Research Institute as described by Bennion and Bamford [11].

\subsection{Statistical Analysis}

The analytical data were analyzed using SPSS 16.0 software. Means and standard deviations were determined using descriptive statistics. Comparisons between samples were determined using analysis of one-way variance (ANOVA) and multiple range tests followed by Duncan test. Statistical significance was defined at $\mathrm{P} \leq 0.05$ according to Steel and Torrie [41].

\section{Results and Discussion}

\subsection{Chemical Analyses of the Sweet Sorghum Products}

Table (2) showed chemical composition of Roma sweet sorghum variety syrup, and freeze-dried juice. Moisture content in sweet sorghum syrups recorded 27\%. Meanwhile, the moisture content was $9.7 \%$ in freeze-dried juice and as a result the shelf-life is increased for these products, similar results were reported by Hatamipour et al. [19].

The data also summarized that; freeze-dried product contained the highest percentage of TSS $(90.30 \%)$ followed by syrup product $(73.00 \%)$. Freeze-dried juice had high profile sugar i.e. sucrose, glucose and fructose than other tested product that means it had the highest total sugars. Total soluble solids enable the syrups to be utilized as sweeteners or preservatives in food products such as juices, drinks, dairy, bakery and confectionery products Elena [15].

Table (2) also, indicated that all the tested products contained reasonable amount of total phenol and menials.

These results are in line with data obtained by Helmy [20] who mentioned that increased total solid content of syrup also increased its sucrose content and reducing sugars. Meanwhile the freeze-dried juice had the highest value (50\%) of sucrose followed by syrup (44.15\%). Reducing sugars content was low in syrup $(20.92 \%)$ compared to freeze-dried juice $(35.05 \%)$, heating juice for a long time during syrup processing leads to an increase in the sucrose inversion to reducing sugars. Glucose ratio, which refers to the relationship between juice content of glucose and sucrose, and therefore, increasing in the glucose ratio values is considered as a good indicator in syrup quality.

Table 2. Chemical Properties of Sweet Sorghum Products.

\begin{tabular}{lll}
\hline \multirow{2}{*}{ Components (\%) } & \multicolumn{2}{l}{ Sweet Sorghum Products } \\
\cline { 2 - 3 } & Syrup & Freeze-dried Juice \\
\hline Moisture & $27.00 \pm 0.21$ & $9.70 \pm 0.11$ \\
Total soluble solids & $73.00 \pm 0.17$ & $90.3 \pm 0.16$ \\
Sucrose (S) & $44.15 \pm 0.14$ & $50.00 \pm 0.17$ \\
Glucose (G) & $12.30 \pm 0.23$ & $18.03 \pm 0.18$ \\
\hline
\end{tabular}




\begin{tabular}{lll}
\hline \multirow{2}{*}{ Components (\%) } & \multicolumn{2}{l}{ Sweet Sorghum Products } \\
\cline { 2 - 3 } & Syrup & Freeze-dried Juice \\
\hline Fructose (F) & $8.62 \pm 0.12$ & $13.02 \pm 0.14$ \\
Reducing sugars & $20.92 \pm 0.20$ & $35.05 \pm 0.15$ \\
Total sugar & $65.07 \pm 0.18$ & $85.05 \pm 0.19$ \\
Glucose ratio & $0.28 \pm 0.17$ & $0.38 \pm 0.12$ \\
Starch & $0.90 \pm 0.21$ & $0.85 \pm 0.11$ \\
Ash & $4.5 \pm 0.11$ & $4.7 \pm 0.14$ \\
Crud Protein\% & $4.45 \pm 0.13$ & $5.82 \pm 0.12$ \\
Non-sugar substances & $7.93 \pm 0.12$ & $5.25 \pm 0.13$ \\
Total phenols (mg GAE/100 g) & $455.5 \pm 0.15$ & $489.2 \pm 0.19$ \\
**HMF (ppm) & $15 \pm 0.23$ & $35 \pm 0.22$ \\
Minerals\% & & \\
Potassium (K) & $1.139 \pm 0.13$ & $1.160 \pm 0.13$ \\
Calcium (Ca) & $0.274 \pm 0.15$ & $0.309 \pm 0.17$ \\
Ferric (Fe) & $0.084 \pm 0.12$ & $0.116 \pm 0.15$ \\
\hline
\end{tabular}

*Data are expressed as mg gallic acid equivalents (GAE) per $100 \mathrm{~g}$ sample, ** 5-hydroxymethylfurfura

The starch content in syrup and freeze-dried juice recorded $(0.90$ and $0.85 \%)$, respectively. Similar results were attributed by Nan et al. [30] who found that the starch content in the juice of sweet sorghum ranging from 300 to $9900 \mathrm{ppm}$ and most of them were around $2000 \mathrm{ppm}$. Ash percent increased with increased juice concentration. These results are in agreement with those of El-Geddawy [16] who found that sweet sorghum syrup contains $5.61 \%$ protein and ash ranging between 2.1 and $4.17 \%$. Abazied [3] mentioned that non-sugar substances, upon heating juice for a long time, during syrup processing, leads to the coagulation of some non-sugar substances such as the-proteins and some plant pigments, which means lower purity. Data also cleared that sweet sorghum products had a high content of phenolic compounds. These results are in line with results of AlAskalani and Khalil [7] who mentioned that phenolic compounds in some sweet sorghum varieties reaches up to $6 \%$, thus it was suitable for industrial processing.

HMF content in syrup gave lowest value compared to freeze dried juice. Jafarnia et al. [21] reported that Hydroxymethylfurfural (HMF) is a common Maillard reaction product directly formed from dehydration of sugars under acidic conditions during heating and storage in carbohydrate rich foods and also mentioned that the maximum levels of HMF were between $5.5-37.7 \mathrm{mg} \mathrm{kg}$ in date syrup.

Moreover, data in the same table showed a gradual increase in minerals content of sweet sorghum products i.e. $\mathrm{K} \%, \mathrm{Ca} \%$ and $\mathrm{Fe} \%$ by concentration process of sweet sorghum juice. These results are in line with those of Elena [15].

\subsection{Physical Properties of Sweet Sorghum Products}

Physical characteristics $(\mathrm{pH}$, titratable acidity, sweetness acceptability, power sweetener and colour evaluation) of sweet sorghum syrup and freeze-dried juice are illustrated in Table (3). Sweet sorghum syrup with $\mathrm{pH}$ value (4.6) contained total acidity $(0.45) \%$ while, freeze-dried juice with $\mathrm{pH}$ value (4.7) contained total acidity $(0.49) \%$. The results may be due to the rise in the content of titratable acidity in the fresh juice by concentration processing and decomposition of some reducing sugars which leads to formation of some organic acids. This characteristic can affect the syrup quality since the total acidity gives the syrup their distinctive taste and flavor in the final syrup. These results are in agreement with those of Abazied [3] and Helmy [22] they mentioned that high titratable acidity may be due to the reaction between the unstable organic substances with reducing sugars during processing.

The obtained data in table (3) indicated that, freeze-dried juice product possessed a good sweetness acceptability and highest power sweetener than the other product.

Regarding power sweetener, the freeze-dried juice showed the highest value followed by syrup. This result was logical because concentration of juice during manufacturing of this product caused an increase in TSS\% which is near to the total sugars amount. A similar result was found in work by Abazied [3] and Helmy [22].

Table 3. Physical Properties of Sweet Sorghum Products.

\begin{tabular}{lll}
\hline \multirow{2}{*}{ Characteristics } & \multicolumn{2}{l}{ Sweet Sorghum Products } \\
\cline { 2 - 3 } & Syrup & Freeze-dried Juice \\
\hline $\mathrm{pH}$ & $4.60 \pm 0.17$ & $4.7 \pm 0.10$ \\
Total Acidity\% & $0.45 \pm 0.02$ & $0.49 \pm 0.13$ \\
Sweetness acceptability (Score & $9.00 \pm 0.25$ & $9.50 \pm 0.22$ \\
10) & $65.57 \pm 0.14$ & $81.97 \pm 0.17$ \\
*Power sweetener & & \\
Colour evaluation & $11.01 \pm 0.11$ & $47.01 \pm 0.17$ \\
$\mathrm{~L}^{*}$ & $3.28 \pm 0.10$ & $-4.86 \pm 0.14$ \\
$\mathrm{a}^{*}$ & $2.09 \pm 0.13$ & $20.20 \pm 0.12$ \\
$\mathrm{~b}^{*}$ & $0.38 \pm 0.20$ & $0.27 \pm 0.19$ \\
Hue & $3.89 \pm 0.14$ & $20.78 \pm 0.15$ \\
Chroma (Apparent purity\%) & $0.34 \pm 0.20$ & $0.27 \pm 0.31$ \\
Browning index $(\mathrm{BI})$ & $51.40 \pm 0.21$ & $11.67 \pm 0.17$ \\
Total colour difference $(\Delta \mathrm{E})$ & \\
\hline
\end{tabular}

*Not's: Power sweetener calculated as a relative sweetness of sugar fractionation $(\mathrm{S}=1, \mathrm{G}=0.69, \mathrm{~F}=1.5)$;

*TA: as $\mathrm{ml} \mathrm{Na} \mathrm{OH} 0.1 \mathrm{~N} / 100 \mathrm{~g}$ sample and calculated by $(\mathrm{mg} / \mathrm{m} \mathrm{Eq}$ as a citric acid)

The colour evaluation for the tested products demonstrated that, the freeze-dried juice product had a higher value of chroma, meanwhile, the syrup was the highest for browning index (Table 3).

Total colour difference and chroma was considered as the most sensitive parameter for the measurement of colour change in syrup and freeze-dried juice. Data in table 3 also showed the highest value of lightness in freeze-dried juice followed by syrup. Meanwhile, syrup color tends to be more red and less yellow, as measured by the Hunter Lab Spectrophotometer. These results are in line with those of Akbulut and Özcan [6] they mentioned that non-enzymatic browning is manly associated with carbohydrate degradation reactions, such as the maillard and caramelization reactions. Meanwhile the freeze-dried juice colour tended to be more yellow and less green. The difference of total colour $(\Delta \mathrm{E})$ and chroma are the most important parameter for the measurement of colour change in syrup and freeze- dried juice. Therefore, the results observed showed that a high colour difference between juice and thermally process 
(syrup) and freeze- dried.

In accordance to physico-chemical characteristics and nutritional profile of syrup and freeze-dried juice; sweet sorghum products were used for preparation of cakes as a source of sugar.

\subsection{Physical Properties of Cake Prepared with Sweet Sorghum Products}

One of the most important physical properties of cake is porous structure which formed through air bulb expansion and volume development during baking. Data illustrated in Table (4) showed that, the prepared cakes with replacement of sugar by $40 \%$ sweet sorghum syrup significantly had lower cake height and volume than those prepared with sucrose (control). It is concluded that, when the sweet sorghum syrup replacement was increased, the height and volume of cake decreased. The current results in agreement with results by Murano and Johnson [29] on yellow cake produced with high fructose syrup.

No significant difference was found between cakes which were prepared with $25 \%$ freeze-dried sweet sorghum juice when compared with control. When replacement ratio increased (up to $100 \%$ ), the height and volume of cake decreased. Koepsel and Hoseney [24], found that, the lower volume of cake was attributed to less air incorporated on mixing and early gelatinization of the starch during baking.
The specific volume of a cake can be used as an indicator of volume development and consequently of the porous structure of the product. The $40 \%$ sweet sorghum syrup cakes, significantly had the lowest specific volume, while the cakes made with up to $50 \%$ freeze-dried juice showed high specific volume without significant differences between it and control cake. The obtained data also summarized that, when sugar replacement increased, the specific volume decreased. Bean et al. [10] explained the lower specific volume of fructose cakes, in his study, by the effect of fructose to set starch gelatinization, and thus strengthening of structure, at lower temperature, before the full development of air bubbles.

Regarding the moisture content of cakes, it is increased significantly by increasing the ratio of syrup. While the moisture content of freeze-dried sweet sorghum juice cakes showed a slight significant difference than control.

Significant differences in water activity were detected between control cake and cakes with sweet sorghum syrup having significantly higher values. The water activity affects the shelf-life stability of the product. However, the observed differences are rather small and consequently not expected to considerably affect the growth of microorganisms. No significant differences, in water activity, were detected between the control cake and cakes with freeze dried sweet sorghum juice.

Table 4. Physical Evaluation of Cakes with Sweet Sorghum Products.

\begin{tabular}{|c|c|c|c|c|c|c|}
\hline Substitute Ratio & Height (cm) & Volume $\left(\mathrm{cm}^{3}\right)$ & Weight (g) & Specific Volume (V/W) & Moisture (\%) & Water Activity \\
\hline \multicolumn{7}{|c|}{ Cake with Sweet Sorghum Syrup } \\
\hline Control & $5.75 \pm 0.11^{\mathrm{a}}$ & $154.78 \pm 0.19^{\mathrm{a}}$ & $91.79 \pm 0.10^{\mathrm{c}}$ & $1.69 \pm 0.15^{\mathrm{a}}$ & $30.59 \pm 0.10^{\mathrm{e}}$ & $0.932 \pm 0.16^{\mathrm{b}}$ \\
\hline 10 & $5.74 \pm 0.17^{\mathrm{a}}$ & $153.92 \pm 0.12^{\mathrm{a}}$ & $91.96 \pm 0.14^{\mathrm{c}}$ & $1.67 \pm 0.10^{\mathrm{ab}}$ & $31.72 \pm 0.14^{\mathrm{d}}$ & $0.943 \pm 0.11^{\mathrm{a}}$ \\
\hline 20 & $5.72 \pm 0.13^{\mathrm{ab}}$ & $153.35 \pm 0.14^{\mathrm{ab}}$ & $93.55 \pm 0.14^{\mathrm{bc}}$ & $1.64 \pm 0.13^{\mathrm{bc}}$ & $32.00 \pm 0.12^{\mathrm{c}}$ & $0.943 \pm 0.15^{\mathrm{a}}$ \\
\hline 30 & $5.66 \pm 0.19^{b}$ & $152.16 \pm 0.16^{\mathrm{b}}$ & $95.15 \pm 0.17^{\mathrm{b}}$ & $1.60 \pm 0.16^{\mathrm{c}}$ & $33.12 \pm 0.17^{\mathrm{b}}$ & $0.945 \pm 0.19^{\mathrm{a}}$ \\
\hline 40 & $5.08 \pm 0.14^{\mathrm{c}}$ & $139.93 \pm 0.15^{\mathrm{c}}$ & $100.00 \pm 0.12^{\mathrm{a}}$ & $1.40 \pm 0.12^{\mathrm{d}}$ & $33.71 \pm 0.14^{\mathrm{a}}$ & $0.945 \pm 0.13^{\mathrm{a}}$ \\
\hline \multicolumn{7}{|c|}{ Cake with Freeze-Dried Sweet Sorghum Juice } \\
\hline 25 & $5.73 \pm 0.15^{\mathrm{a}}$ & $154.23 \pm 0.10^{\mathrm{a}}$ & $92.14 \pm 0.15^{\mathrm{c}}$ & $1.68 \pm 0.10^{\mathrm{a}}$ & $30.68 \pm 0.11^{\mathrm{ab}}$ & $0.932 \pm 0.17^{\mathrm{a}}$ \\
\hline 50 & $5.72 \pm 0.17^{\mathrm{ab}}$ & $153.52 \pm 0.13^{\mathrm{ab}}$ & $92.26 \pm 0.12^{\mathrm{c}}$ & $1.66 \pm 0.16^{\mathrm{a}}$ & $30.71 \pm 0.15^{\mathrm{ab}}$ & $0.933 \pm 0.11^{\mathrm{a}}$ \\
\hline 75 & $5.68 \pm 0.12^{\mathrm{b}}$ & $152.21 \pm 0.11^{\mathrm{b}}$ & $95.19 \pm 0.19^{\mathrm{b}}$ & $1.59 \pm 0.12^{b}$ & $30.90 \pm 0.14^{\mathrm{a}}$ & $0.933 \pm 0.14^{\mathrm{a}}$ \\
\hline 100 & $5.65 \pm 0.16^{\mathrm{c}}$ & $151.42 \pm 0.10^{\mathrm{c}}$ & $97.52 \pm 0.13^{\mathrm{a}}$ & $1.55 \pm 0.10^{\mathrm{c}}$ & $31.10 \pm 0.19^{\mathrm{a}}$ & $0.934 \pm 0.12^{\mathrm{a}}$ \\
\hline
\end{tabular}

*Values are means of three replicates $\pm \mathrm{SD}$, number in the same column followed by the same letter are not significantly different at 0.05 level.

\subsection{Colour Parameters of Cake}

Crust color was significantly affected by the replacement of sucrose with sweet sorghum products (Table 5). Total colour difference $(\Delta \mathrm{E})$ showed significant difference from control. In general, as the sweet sorghum syrup increased, the crust color became darker, more red and more yellow, as measured by the Hunter Lab Spectrophotometer (Table 5).
These results agree with the study of Porabolghasem and Ayoubi [32] on date syrup as sugar replacement in cupcake in which the substitution in much browner exteriors. The bvalues (yellowness) for 20 and $40 \%$ sweet sorghum syrup cakes were higher than that of control (Table 5). The crusts of the control cakes were yellower $(\mathrm{P}<0.05)$ than the crusts of all other cakes.

Table 5. Colour Evaluation of Cakes with Sweet Sorghum Products.

\begin{tabular}{|c|c|c|c|c|c|c|c|c|}
\hline & \multicolumn{4}{|l|}{ Crust Colour } & \multicolumn{4}{|c|}{ Crumb Colour } \\
\hline & $\mathbf{L}$ & $\mathbf{a}$ & $\mathbf{b}$ & $\Delta \mathbf{E}$ & $\mathbf{L}$ & $\mathbf{a}$ & b & $\Delta \mathbf{E}$ \\
\hline \multicolumn{9}{|c|}{ Cake with Sweet Sorghum Syrup } \\
\hline Control & $57.01 \pm 0.17^{\mathrm{a}}$ & $7.86 \pm 0.14^{\mathrm{e}}$ & $10.98 \pm 0.10^{\mathrm{e}}$ & - & $83.46 \pm 0.19^{\mathrm{a}}$ & $-3.04 \pm 0.13^{\mathrm{e}}$ & $9.72 \pm 0.10^{\mathrm{e}}$ & - \\
\hline 10 & $55.50 \pm 0.16^{\mathrm{b}}$ & $8.45 \pm 0.10^{\mathrm{d}}$ & $11.28 \pm 0.18^{\mathrm{d}}$ & $1.65 \pm 0.11^{\mathrm{d}}$ & $83.12 \pm 0.22^{\mathrm{b}}$ & $-2.82 \pm 0.18^{\mathrm{d}}$ & $12.76 \pm 0.10^{\mathrm{d}}$ & $3.06 \pm 0.19^{\mathrm{d}}$ \\
\hline 20 & $51.00 \pm 0.11^{\mathrm{c}}$ & $9.53 \pm 0.17^{\mathrm{c}}$ & $11.88 \pm 0.16^{\mathrm{c}}$ & $6.30 \pm 0.15^{\mathrm{c}}$ & $82.82 \pm 0.19^{c}$ & $-2.50 \pm 0.10^{\mathrm{c}}$ & $14.25 \pm 0.12^{\mathrm{c}}$ & $4.61 \pm 0.14^{\mathrm{c}}$ \\
\hline 30 & $49.49 \pm 0.13^{\mathrm{d}}$ & $9.66 \pm 0.15^{\mathrm{b}}$ & $12.28 \pm 0.14^{\mathrm{b}}$ & $7.83 \pm 0.11^{\mathrm{b}}$ & $81.86 \pm 0.11^{\mathrm{d}}$ & $-2.38 \pm 0.12^{\mathrm{b}}$ & $14.39 \pm 0.18^{\mathrm{b}}$ & $4.98 \pm 0.11^{b}$ \\
\hline
\end{tabular}




\begin{tabular}{|c|c|c|c|c|c|c|c|c|}
\hline & \multicolumn{4}{|l|}{ Crust Colour } & \multicolumn{4}{|c|}{ Crumb Colour } \\
\hline & $\mathbf{L}$ & $\mathbf{a}$ & b & $\Delta \mathbf{E}$ & $\mathbf{L}$ & $\mathbf{a}$ & b & $\Delta \mathbf{E}$ \\
\hline 40 & $47.10 \pm 0.17^{\mathrm{e}}$ & $9.77 \pm 0.13^{\mathrm{a}}$ & $13.79 \pm 0.10^{\mathrm{a}}$ & $10.48 \pm 0.19^{\mathrm{a}}$ & $80.63 \pm 0.19^{\mathrm{e}}$ & $-2.20 \pm 0.15^{\mathrm{a}}$ & $15.58 \pm 0.15^{\mathrm{a}}$ & $6.56 \pm 0.13^{\mathrm{a}}$ \\
\hline \multicolumn{9}{|c|}{ Cake with Freeze-Dried of Sweet Sorghum Juice } \\
\hline Control & $57.01 \pm 0.17^{\mathrm{a}}$ & $7.86 \pm 0.14^{\mathrm{e}}$ & $10.98 \pm 0.10^{\mathrm{e}}$ & - & $83.46 \pm 0.19^{\mathrm{a}}$ & $-3.04 \pm 0.13^{\mathrm{e}}$ & $9.72 \pm 0.10^{\mathrm{e}}$ & - \\
\hline 25 & $55.21 \pm 0.16^{\mathrm{b}}$ & $8.95 \pm 0.10^{\mathrm{d}}$ & $11.08 \pm 0.18^{\mathrm{d}}$ & $2.11 \pm 0.11^{\mathrm{d}}$ & $83.52 \pm 0.22^{\mathrm{b}}$ & $-2.89 \pm 0.18^{\mathrm{d}}$ & $12.89 \pm 0.10^{\mathrm{d}}$ & $3.17 \pm 0.19^{d}$ \\
\hline 50 & $51.50 \pm 0.11^{\mathrm{c}}$ & $9.33 \pm 0.17^{\mathrm{c}}$ & $11.78 \pm 0.16^{\mathrm{c}}$ & $5.76 \pm 0.15^{\mathrm{c}}$ & $82.75 \pm 0.19^{\mathrm{cj}}$ & $-2.55 \pm 0.10^{c}$ & $14.15 \pm 0.12^{\mathrm{c}}$ & $4.51 \pm 0.14^{\mathrm{c}}$ \\
\hline 75 & $49.89 \pm 0.13^{\mathrm{d}}$ & $9.46 \pm 0.15^{\mathrm{b}}$ & $12.08 \pm 0.14^{\mathrm{b}}$ & $7.38 \pm 0.11^{\mathrm{b}}$ & $81.67 \pm 0.11^{\mathrm{d}}$ & $-2.44 \pm 0.12^{\mathrm{b}}$ & $14.33 \pm 0.18^{\mathrm{b}}$ & $4.98 \pm 0.11^{\mathrm{b}}$ \\
\hline 100 & $47.50 \pm 0.17^{\mathrm{e}}$ & $9.57 \pm 0.13^{\mathrm{a}}$ & $13.59 \pm 0.10^{\mathrm{a}}$ & $10.01 \pm 0.19^{\mathrm{a}}$ & $80.50 \pm 0.19^{\mathrm{e}}$ & $-2.28 \pm 0.15^{\mathrm{a}}$ & $14.54 \pm 0.15^{\mathrm{a}}$ & $5.71 \pm 0.13^{\mathrm{a}}$ \\
\hline
\end{tabular}

L (lightness with L = 100 for lightness, and L = zero for darkness), a [(chromaticity on a green (-) to red (+)], b [(chromaticity on a برجاء التاكد $(+)]$ *Values are means of three replicates \pm SD, number in the same column followed by the same letter are not significantly different at 0.05 level.

Although crumb b-values (yellowness) increased, crumb L-values (lightness) and a-values (greenness) were not different (Table 5). As the level of sweet sorghum increased, the b-values increased, indicating a yellower crumb. These results agree with results of shortened cakes in which the use of high fructose corn syrup caused the development of uncharacteristic yellowish or greenish interior colors which was attributed, by Volpe and Meres [36], to Maillard reactions. Darkening was caused by the amount of reducing sugars available to participate in the Maillard browning reaction. This non-enzymatic reaction occurs when a reducing sugar (fructose) and protein are heated together.

The results indicated that a darker crust and crumb would be obtained from the substitution of sugar by freeze dried juice which is increased with the increase of substitution levels. Since there was an increase in fructose with the addition of sweet sorghum, the intensity in the degree of the reaction rate was observed. Moreover, since the temperature on the surface of the cake is higher than within the interior of the cake, there would be a higher degree of browning on the crust rather than of the crumb. These results are in agreement with studies by Addo [5].

\subsection{Chemical Evaluation of Cakes}

Concerning the chemical analysis of cakes produced with both forms of sweet sorghum juice, it can be noticed that the protein content increased as the substitution level increased. Data in Table (6) showed that the $100 \%$ substitution with freeze-dried sweet sorghum juice resulted in a high protein content (17.20\%). The results agree with work by El-Geddawy [16], who reported that protein level increased from 8.31 to 10.16 in biscuits with $50 \%$ sweet sorghum syrup. Data in Table (6) demonstrated that, fat content was non-significantly $(p>0.05)$ affected by the different substitution levels of sweet sorghum products.

It could be noticed that, ash content increased as substitution ratio increased. These results are higher than that obtained by Rezq [34] who reported that biscuits prepare with sweet sorghum syrup contained $1.22 \%$ ash.

Concerning the total carbohydrate content, it was significantly decreased as the substitution level of sweet sorghum syrup increased. Similar results were obtained by El-Geddawy [16]. While, Messiaen [28], reported that the higher protein, fat, ash content, the lower values of the carbohydrates.

Table 6. Chemical Evaluation of Cakes with Sweet Sorghum Products.

\begin{tabular}{|c|c|c|c|c|c|c|c|c|}
\hline & Protein & Fat & Ash & Fiber & Carbo-hydrates & Total Sugar & Reducing Sugar & $\begin{array}{l}\text { Non-Reducing } \\
\text { Sugar }\end{array}$ \\
\hline \multicolumn{9}{|c|}{ Cake with Sweet Sorghum Syrup } \\
\hline Control & $11.38 \pm 0.10^{\mathrm{e}}$ & $16.90 \pm 0.18^{\mathrm{a}}$ & $1.05 \pm 0.14^{\mathrm{e}}$ & $5.15 \pm 0.10^{\mathrm{b}}$ & $70.67 \pm 0.15^{\mathrm{a}}$ & $44.31 \pm 0.13^{\mathrm{a}}$ & $1.80 \pm 0.11^{\mathrm{e}}$ & $42.50 \pm 0.15^{\mathrm{a}}$ \\
\hline 10 & $11.83 \pm 0.18^{\mathrm{d}}$ & $16.95 \pm 0.17^{\mathrm{a}}$ & $1.45 \pm 0.10^{\mathrm{d}}$ & $5.16 \pm 0.17^{\mathrm{ab}}$ & $69.77 \pm 0.11^{\mathrm{b}}$ & $42.84 \pm 0.13^{\mathrm{b}}$ & $2.59 \pm 0.18^{d}$ & $40.25 \pm 0.11^{\mathrm{b}}$ \\
\hline 20 & $12.27 \pm 0.10^{\mathrm{c}}$ & $16.94 \pm 0.14^{\mathrm{a}}$ & $1.99 \pm 0.15^{\mathrm{c}}$ & $5.16 \pm 0.15^{\mathrm{ab}}$ & $68.80 \pm 0.17^{\mathrm{c}}$ & $41.38 \pm 0.10^{\mathrm{c}}$ & $3.38 \pm 0.15^{\mathrm{c}}$ & $38.00 \pm 0.13^{\mathrm{c}}$ \\
\hline 30 & $12.72 \pm 0.17^{\mathrm{b}}$ & $16.93 \pm 0.12^{\mathrm{a}}$ & $2.40 \pm 0.18^{b}$ & $5.17 \pm 0.12^{\mathrm{ab}}$ & $67.91 \pm 0.14^{\mathrm{d}}$ & $39.92 \pm 0.18^{\mathrm{d}}$ & $4.20 \pm 0.10^{\mathrm{b}}$ & $35.75 \pm 0.17^{\mathrm{d}}$ \\
\hline 40 & $13.16 \pm 0.12^{\mathrm{a}}$ & $16.92 \pm 0.10^{\mathrm{a}}$ & $2.85 \pm 0.12^{\mathrm{a}}$ & $5.18 \pm 0.12^{\mathrm{a}}$ & $67.07 \pm 0.12^{\mathrm{e}}$ & $38.46 \pm 0.10^{\mathrm{e}}$ & $4.96 \pm 0.13^{\mathrm{a}}$ & $33.50 \pm 0.10^{\mathrm{e}}$ \\
\hline \multicolumn{9}{|c|}{ Cake with Freeze-Dried Sweet Sorghum Juice } \\
\hline Control & $11.38 \pm 0.10^{\mathrm{e}}$ & $16.90 \pm 0.18^{\mathrm{a}}$ & $1.05 \pm 0.14^{\mathrm{e}}$ & $5.15 \pm 0.10^{\mathrm{b}}$ & $70.67 \pm 0.15^{\mathrm{a}}$ & $44.31 \pm 0.13^{\mathrm{a}}$ & $1.80 \pm 0.11^{\mathrm{e}}$ & $42.50 \pm 0.15^{\mathrm{a}}$ \\
\hline 25 & $12.36 \pm 0.14^{\mathrm{d}}$ & $16.95 \pm 0.13^{\mathrm{a}}$ & $2.10 \pm 0.10^{\mathrm{d}}$ & $5.16 \pm 0.17^{\mathrm{ab}}$ & $68.59 \pm 0.18^{\mathrm{b}}$ & $42.92 \pm 0.15^{\mathrm{b}}$ & $5.48 \pm 0.17^{\mathrm{d}}$ & $37.43 \pm 0.18^{\mathrm{b}}$ \\
\hline 50 & $14.29 \pm 0.17^{\mathrm{c}}$ & $16.93 \pm 0.14^{\mathrm{a}}$ & $2.88 \pm 0.11^{\mathrm{c}}$ & $5.17 \pm 0.15^{\mathrm{a}}$ & $65.90 \pm 0.11^{\mathrm{c}}$ & $41.42 \pm 0.18^{\mathrm{c}}$ & $9.15 \pm 0.13^{\mathrm{c}}$ & $32.27 \pm 0.10^{\mathrm{c}}$ \\
\hline 75 & $15.75 \pm 0.13^{b}$ & $16.92 \pm 0.15^{\mathrm{a}}$ & $3.37 \pm 0.18^{b}$ & $5.17 \pm 0.12^{\mathrm{a}}$ & $63.96 \pm 0.14^{\mathrm{d}}$ & $40.20 \pm 0.10^{\mathrm{d}}$ & $13.11 \pm 0.11^{\mathrm{b}}$ & $27.12 \pm 0.14^{\mathrm{d}}$ \\
\hline 100 & $17.20 \pm 0.18^{\mathrm{a}}$ & $16.94 \pm 0.10^{\mathrm{a}}$ & $3.60 \pm 0.13^{\mathrm{a}}$ & $5.17 \pm 0.12^{\mathrm{a}}$ & $62.26 \pm 0.12^{\mathrm{e}}$ & $38.80 \pm 0.15^{\mathrm{e}}$ & $16.90 \pm 0.14^{\mathrm{a}}$ & $21.93 \pm 0.17^{\mathrm{e}}$ \\
\hline
\end{tabular}

*Values are means of three replicates $\pm \mathrm{SD}$, number in the same column followed by the same letter are not significantly different at 0.05 level.

Total sugars were reduced significantly as the replacement levels increased. This may be due to the lower amounts of total sugars in sweet sorghum products (ranging between $65.07 \%$ for sweet sorghum syrup and $85.05 \%$, for freezedried sweet sorghum juice). Reducing sugar levels also increased as the replacement levels increased. This may be a result of the higher amounts of reducing sugars in sweet sorghum products (ranging between $20.92 \%$ and $35.05 \%$ ) than in sucrose. As for non-reducing sugars, values decreased as the substation level increased.

\subsection{Sensory Evaluation of Cakes}

Data in Table (7) demonstrated that acceptable cakes were made with sweet sorghum syrup, up to $20 \%$ in replacement 
for sucrose. While $40 \%$ replacement with syrup had got the lowest score in the overall acceptance (only 7.03). These results agree with work by McCoullough et al. [27], who reported that the taste panel rated the all sucrose cake significantly more acceptable than the cakes prepared with high fructose corn syrup because of the compact, lower volume.

Cakes with freeze-dried sweet sorghum juice were acceptable, with no significant difference from control, up to $50 \%$ replacement. But both texture and moistness are negatively affected by the substitution level.

Table 7. Sensory Evaluation of Cakes with Sweet Sorghum Products.

\begin{tabular}{|c|c|c|c|c|c|c|c|c|}
\hline & $\begin{array}{l}\text { Crust } \\
\text { Colour (10) }\end{array}$ & $\begin{array}{l}\text { Crumb } \\
\text { Colour (10) } \\
\end{array}$ & Texture (10) & $\begin{array}{l}\text { Moistness } \\
\text { (10) } \\
\end{array}$ & Flavour (10) & Taste (10) & $\begin{array}{l}\text { Appearance } \\
(10)\end{array}$ & $\begin{array}{l}\text { Overall } \\
\text { Acceptance (10) }\end{array}$ \\
\hline \multicolumn{9}{|c|}{ Cake with Sweet Sorghum Syrup } \\
\hline Control & $9.64 \pm 0.11^{\mathrm{a}}$ & $9.32 \pm 0.14^{\mathrm{a}}$ & $9.68 \pm 0.16^{\mathrm{a}}$ & $9.61 \pm 0.12^{\mathrm{a}}$ & $9.66 \pm 0.16^{\mathrm{a}}$ & $9.74 \pm 0.13^{\mathrm{a}}$ & $9.43 \pm 0.10^{\mathrm{a}}$ & $9.82 \pm 0.15^{\mathrm{a}}$ \\
\hline 10 & $9.59 \pm 0.13^{\mathrm{a}}$ & $9.27 \pm 0.12^{\mathrm{a}}$ & $9.59 \pm 0.1 \mathrm{ab}^{\mathrm{b}}$ & $9.59 \pm 0.14^{\mathrm{a}}$ & $9.03 \pm 0.11^{\mathrm{b}}$ & $9.72 \pm 0.11^{\mathrm{a}}$ & $9.41 \pm 0.16^{\mathrm{a}}$ & $9.72 \pm 0.16^{\mathrm{a}}$ \\
\hline 20 & $9.55 \pm 0.16^{\mathrm{a}}$ & $8.95 \pm 0.11^{\mathrm{b}}$ & $9.55 \pm 0.1 \mathrm{~b}^{\mathrm{b}}$ & $9.44 \pm 0.11^{\mathrm{b}}$ & $8.77 \pm 0.12^{\mathrm{c}}$ & $9.70 \pm 0.15^{\mathrm{a}}$ & $9.23 \pm 0.14^{\mathrm{b}}$ & $9.53 \pm 0.12^{\mathrm{b}}$ \\
\hline 30 & $9.10 \pm 0.10^{\mathrm{b}}$ & $8.53 \pm 0.15^{\mathrm{c}}$ & $9.10 \pm 0.14^{\mathrm{c}}$ & $8.95 \pm 0.10^{\mathrm{c}}$ & $8.04 \pm 0.14^{\mathrm{d}}$ & $9.14 \pm 0.16^{\mathrm{b}}$ & $8.42 \pm 0.12^{\mathrm{c}}$ & $8.03 \pm 0.14^{\mathrm{c}}$ \\
\hline 40 & $8.00 \pm 0.14^{\mathrm{c}}$ & $7.92 \pm 0.15^{\mathrm{d}}$ & $8.00 \pm 0.15^{\mathrm{d}}$ & $8.21 \pm 0.12^{\mathrm{d}}$ & $7.67 \pm 0.15^{\mathrm{e}}$ & $8.63 \pm 0.10^{c}$ & $7.01 \pm 0.11^{\mathrm{d}}$ & $7.03 \pm 0.11^{\mathrm{d}}$ \\
\hline Control & $9.64 \pm 0.11^{\mathrm{a}}$ & $9.32 \pm 0.14^{\mathrm{a}}$ & $9.68 \pm 0.16^{\mathrm{a}}$ & $9.61 \pm 0.12^{\mathrm{a}}$ & $9.66 \pm 0.16^{\mathrm{a}}$ & $9.74 \pm 0.13^{\mathrm{a}}$ & $9.43 \pm 0.10^{\mathrm{a}}$ & $9.82 \pm 0.15^{\mathrm{a}}$ \\
\hline 25 & $9.63 \pm 0.14^{\mathrm{a}}$ & $9.32 \pm 0.10^{\mathrm{a}}$ & $9.64 \pm 0.11^{\mathrm{ab}}$ & $9.57 \pm 0.16^{\mathrm{b}}$ & $9.65 \pm 0.13^{\mathrm{a}}$ & $9.73 \pm 0.10^{\mathrm{a}}$ & $9.42 \pm 0.16^{\mathrm{a}}$ & $9.81 \pm 0.11^{\mathrm{a}}$ \\
\hline 50 & $9.63 \pm 0.16^{\mathrm{a}}$ & $9.31 \pm 0.12^{\mathrm{a}}$ & $9.60 \pm 0.12^{\mathrm{b}}$ & $9.56 \pm 0.14^{\mathrm{b}}$ & $9.64 \pm 0.10^{\mathrm{a}}$ & $9.73 \pm 0.16^{\mathrm{a}}$ & $9.41 \pm 0.11^{\mathrm{a}}$ & $9.81 \pm 0.16^{\mathrm{a}}$ \\
\hline 75 & $9.03 \pm 0.11^{\mathrm{b}}$ & $9.02 \pm 0.13^{b}$ & $9.25 \pm 0.14^{\mathrm{c}}$ & $9.10 \pm 0.10^{\mathrm{c}}$ & $9.15 \pm 0.12^{b}$ & $9.53 \pm 0.13^{\mathrm{b}}$ & $9.12 \pm 0.14^{b}$ & $9.43 \pm 0.10^{\mathrm{b}}$ \\
\hline 100 & $8.53 \pm 0.13^{c}$ & $8.81 \pm 0.14^{\mathrm{c}}$ & $8.27 \pm 0.15^{\mathrm{d}}$ & $8.88 \pm 0.13^{d}$ & $8.97 \pm 0.14^{\mathrm{c}}$ & $8.93 \pm 0.12^{\mathrm{c}}$ & $8.73 \pm 0.12^{\mathrm{c}}$ & $9.11 \pm 0.14^{b}$ \\
\hline
\end{tabular}

*Values are means of three replicates $\pm \mathrm{SD}$, number in the same column followed by the same letter are not significantly different at 0.05 level.

\section{Conclusion}

Using evaporation and drying methods are suitable for the production of syrup and powderized juice of sweet sorghum. These products can be used as a source of sugar in making cake with acceptable organoliptical and quality properties.

\section{References}

[1] A. O. A. C. (2010). Association of Official Analytical Chemists: Official Methods of Analysis. $18^{\text {th }}$ Ed., Washington, D.C., USA.

[2] AACC. (2010): Approved Methods of American Association of Cereal Chemists. St. Paul, USA: American Association of Cereal Chemists.

[3] Abazied, Sakina R. (2013). Chemical and technological studies on sweet sorghum. Ph.D. Thesis Fac. of Sci. South Valley Univ.

[4] Abd El-Hady, E. A.; El-Samahy, S. K.; Mostafa, G. A. and Youssef, K. M. (2002). Use of date bulb and concentrate in rice based extrudates (Einsatez on Date bube und-Konzentrat in Reisextrudaten). Getride, Mehl und Brot., 56 (3): 179185.

[5] Addo, K. (1997). Effects of honey type and level on the baking properties of frozen doughs. Cereal Foods World, 42, $36 \pm 40$.

[6] Akbulut, M. and Özcan, M. M. (2008). Some physical, chemical properties of sweet sorghum (Sorghum bicolor (L) Moench) Pekmez (Molasses). Inter. J. of Food Properties. 11: 79-91.

[7] Al-Askalani, Samia A and Khalil, Soha R. (2015). Using juice of some sweet sorghum varieties in preparing some nutritional products. Egy. J. Nutri. XXX, (3): 65-92.
[8] Almodares, A. and Hadi, M. R. (2009). Production of bioethanol from sweet sorghum: A review, African Journal of Agricultural Research, Vol.5, No.9, (September 2009), pp. 772-780, ISSN 1991-637X.

[9] Awad, A. M. N; Ferweez, H. and Ibrahim, S. M. (2010). Substitution of sugar cane with sweet sorghum stalks in black honey processing. J. Adv. Agric. Res. 15 (2): 375-392.

[10] Bean, M. M., Yamazaki, W. T., and Donelson, D. H. 1978. Wheat starch gelatinization in sugar 526 solutions. II. Fructose, glucose, and sucrose: cake performance. Cereal Chem. 55:945-951.

[11] Bennion, E. B. and Bamford, G. S. T. (1997). The Technology of Cake Making ( 6 ed.). London: Blackie.

[12] Chen, J. C. P. and Picou, R. W. (1972). Cane juice acidity vs sugar recovery. Sugar J. 34 (3): 25-27.

[13] Collins J. L.; Mc Carty, I. E. and Peavy, J. D. (1977). Quality of sorghum syrup produced in tennessee. Farm and Home Science, Report U.S.A., Act. Dec., 104: 12-15.

[14] Datta, S.; Poshadri, A.; Rao, P. S.; Reddy, C. H. R. and Reddy, B. V. S. (2012). Innovative use of sweet sorghum juice in the beverage industry. Inter. Food Res. J. 19 (4): 1361-1366.

[15] Elena, Pîrgari (2007). Sweet sorghum - natural sweetener for foods. Cercetări Agronomice în Moldova Anul XXXX, Vol. 3 (131) / 2007.

[16] El-Geddawy, Yara I. H. (2013). Evaluation the use of sweet sorghum (dough stage) for Manufacture of Some Functional Food Products; M.Sc. Thesis, Depar. of Food Sci., Fac. of Agric., Ain Shams Univ. Cairo.

[17] Folin, O and Ciocalteu, V. (1927). On tyrosine and tryptophane determinations in proteins. J. Biol. Chem. 73(2): 627-650.

[18] Fort, C. A. and Kaig, M. Mc (1939). Comparative chemical composition of juices of different varieties of Louisiana sugar cane. U.S. Dept. Agric. Tech. Bull. 688: 1-68. 
[19] Hatamipour, M. S; Almodares, A.; Ahi, M.; Gorji, M. A. and Jahanshah, Q. (2015). Performance Evaluation of Sweet Sorghum Juice and Sugarcane Molasses for Ethanol Production. Pol. J. Chem. Tech., Vol. 17, No. 3., pp 13-18.

[20] Helmy, Samer A. M (2014). Effect of mineral and biological potassium under different rates of nitrogen fertilization on productivity and technological characteristics of sweet sorghum (sorghum bicolor 1. moench) treacle in Egypt and Ethiopia., Ph.D. Thesis Fac. of Cairo Univ. Insti. of African Res. and studies, Dept. of natural resources.

[21] Jafarnia, A; Soodi, M; and Shekarchi, M. (2016). Determination and comparison of hydroxymethylfurfural in industrial and traditional date syrup products. Iranian Journal of Toxicology. 10 (5): 1-16.

[22] Khuenpet, K.; Charoenjarasrerk, N.; Jaijit, S.; Arayapoonpong, S. and Jittanit, W. (2016). Investigation of suitable spray drying conditions for sugarcane juice powder production with an energy consumption study. Agriculture and Natural Resources 50., 139-145.

[23] Kim, C. S. and Walker, C. E. (1992). Interactions between starches, sugars and emulsifiers in high-ratio cake model systems. Cereal Chemistry, v. 69, n. 2, p. 206-212.

[24] Koepsel, K. M., and Hoseney, R. C. (1980). Effects of corn syrups in layer cakes. Cereal Chem. 57:49.

[25] Long, B. Y., Seiji, Y., Maiko, V. and Wei, C. H. (2006). QTLs for sugar content of stalk in sweet sorghum (Sorghum bicolor L. Moench). Agric. Sci. China 5 (10), 736-744.

[26] Makori, E. M (2013). The potential of sweet sorghum (sorghum bicolor L.) moench as a bio- resource for syrup and ethanol production in Kenya. M.Sc. Thesis, Department of Food Science, Fac. of Agriculture and Technology, Jomo Kenyatta University.

[27] McCoullough, M. A., Johnson, J. M. and Phillips, J. A.
(1986). High fructose corn syrup replacement for sucrose in shortened cakes. J. Food Sci., 51, 534-536.

[28] Messiaen, C. M. (1992). The tropical vegetable garden. Macmillian Ltd. London. pp. 218-247.

[29] Murano, P. S. and Johnson, J. M. (1998). Volume and Sensory Properties of Yellow Cakes as Affected by High Fructose Corn Syrup and Corn Oil. J. Food Sci., 63 (6): 1088-1092.

[30] Nan, L.; Best, G. and De Carvalho Neto, C. C. (1994). Integrated energy systems in China-The cold Northeastern region experience. Food and Agric. Organization Of the United Nations. Rome.

[31] Paton, D.; Larocque, G. M. and Holme, J. (1981). Development of cake structure: influence of ingredients on the measurement of cohesive force during baking. Cereal Chemistry, 58(6), 527-529.

[32] Porabolghasem, M., and Ayoubi, A. (2017). Substituting sugar with date syrup in cupcake. Iranian Food Science and Technology Research Journal, 5(13), 808-819.

[33] Ranganna, S. (1977). Manual of analysis of fruit and vegetable products. New Delhi: Tata McGraw-Hill.

[34] Rezq, A. A. M. (2007). Impact of sweet sorghum syrup on the nutritive value and quality of some baked products. Ph.D. Thesis. (Nutrition and Food Science). Helwan University, Cairo, Egypt. 7 P.

[35] Steel, R. C. and Torrie, J. H. (1980). Principles and procedures statistics. Mc Graw Hill Book Company Inc. New York.

[36] Volpe, T. and Meres, C. (1976). Use of high fructose corn syrups in white layer cake. Bakers Digest 50: 38.

[37] Wilhelm, L. R., Suter, D. A. and Brusewitz, G. H. (2004). Drying and dehydration. Chapter 10 in Food \& Proc., Engin., Tech., 259-284. 